Bull. Mater. Sci., Vol. 10, No. 5, August 1988, pp. 453-460. Q Printed in India.

\title{
Beneficiation of a magnetite-apatite ore from Sung Valley, Shillong, Meghalaya
}

\author{
H K DASGUPTA and S C TALUJA \\ Indian Bureau of Mines, Ajmer 305002 , India \\ Abstract. The beneficiation of apatite from low grade magnetite-apatite ore was studied. \\ Wet magnetic separation followed by flotation was found effective. The effects of different \\ grinds, $\mathrm{pH}$, depressants and collectors at varying dosages were investigated. Various process \\ parameters were optimized and the rougher concentrate was cleaned thrice for improve- \\ ment in the apatite grade. Sodium silicate as depressant, sodium oleate as collector and pine \\ oil as frother, at a $\mathrm{pH}$ of $7-7.5$ (natural $\mathrm{pH}$ ), for apatite flotation were found effective. The \\ general flowsheet of the process was developed.
}

Keywords. Apatite; phosphorite; flotation.

\section{Introduction}

The total reserves of phosphorite and apatite in India are estimated to be around 177 million tonnes and 10 million tonnes respectively. It is likely that the reserves of apatite may go up in the light of new provings in Sung Valley Complex in Meghalaya State. The production of apatite is reported from Andhra Pradesh and West Bengal while that of phosphorite from Madhya Pradesh, Rajasthan and Uttar Pradesh. The indigenous production meets nearly $30 \%$ of the total demand, the balance being met by imports of rock phosphate and phosphoric acid.

Beneficiation of phosphate minerals by flotation is common. However, depending upon the associated calcareous gangue, the method of calcination, quenching and wet screening of the quenched material, is also known.

\section{Ore characteristics}

The sample under study from Sung Valley, Meghalaya State, was mostly as fines, with few lumps, ranging from light brown to steel grey colour and contains predominently magnetite $(65-67 \%)$ with subordinate amounts of apatite $(25-26 \%)$. The other minor minerals include mica $(4-5 \%)$, amphiboles $(2-3 \%)$ and pyroxenes $(1 \%)$. Traces of chlorite, olivine, fluorite, garnet, rutile, quartz and carbonate minerals (combined about $1 \%$ ) were also observed. The possible occurrence of pyrochlore in the ore was also examined but it could not be confirmed by us. Shivananda et al (1981) earlier reported a value of $0.43 \%$ by weight of pyrochlore in the ore.

The magnetite occurred mainly as coarse grains $(0.03$ to $0.30 \mathrm{~mm})$ and also as fine dissemination in apatite. The apatite occurred mostly as subhedral grains $(0.03$ $100.30 \mathrm{~mm}$ ) intermixed with magnetite. Small inclusions of apatite were also observed within magnetite grains. Mica was usually associated with apatite.

The original sample assayed $10 \cdot 5 \% \mathrm{P}_{2} \mathrm{O}_{5}, \quad 4 \cdot 17 \% \mathrm{SiO}_{2}, \quad 53.86 \% \mathrm{Fe}_{2} \mathrm{O}_{3}$, $6.8 \% \mathrm{Al}_{2} \mathrm{O}_{3} .15 \% \mathrm{CaO} .5 \cdot 24 \% \mathrm{MgO}, 0.24 \% \mathrm{~K}_{2} \mathrm{O}, 0 \cdot 18 \% \mathrm{Na}_{2} \mathrm{O}$ and $1.02 \%$ loss on ignition. 


\section{Experimental}

Chemical analysis of various sieve fractions in the minus 10 mesh sample indicated an almost uniform distribution of $\mathrm{P}_{2} \mathrm{O}_{5}$ content, except in the coarser fraction (plus 35 mesh).

The grinding tests were carried on the representative batches of ore samples under the following conditions:

Feed $\quad: 1500 \mathrm{~g}$ minus 10 mesh sample, $67 \%$ solids.

Ball mill : $300 \times 125 \mathrm{~mm}$ Denver with $18.2 \mathrm{~kg}$ ball charge, $54 \mathrm{rpm}$.

Time : 5-20 minutes grinding.

The percent minus 200 mesh fractions thus produced in each, were plotted in the form of Denver standard grindability/hardness graphs. The sample was medium hard in nature as illustrated in figure 1.

The representative batches ground for the above periods were subjected to wet magnetic separation (Ding's; $1-2 \mathrm{kGauss}$ ) and the non-magnetic fractions were subsequently floated.

Flotation was carried out in a $500 \mathrm{~g}$ Denver cell at $20 \%$ pulp density. The other parameters were kept constant as follows: $\mathrm{pH}, 7-7.5$; sodium oleate, $1.6 \mathrm{~kg} / \mathrm{t}$ (unless otherwise specified); pine oil $0.056 \mathrm{~kg} / \mathrm{t}$; conditioning time and flotation time 8 minutes each.

\section{Results and discussion}

\subsection{Optimum grind}

The representative batches of minus 10 mesh sample were ground for $5,8,11,14,17$ and 20 minutes and each subjected to magnetic separation.

The non-magnetics were floated according to the standard procedure described

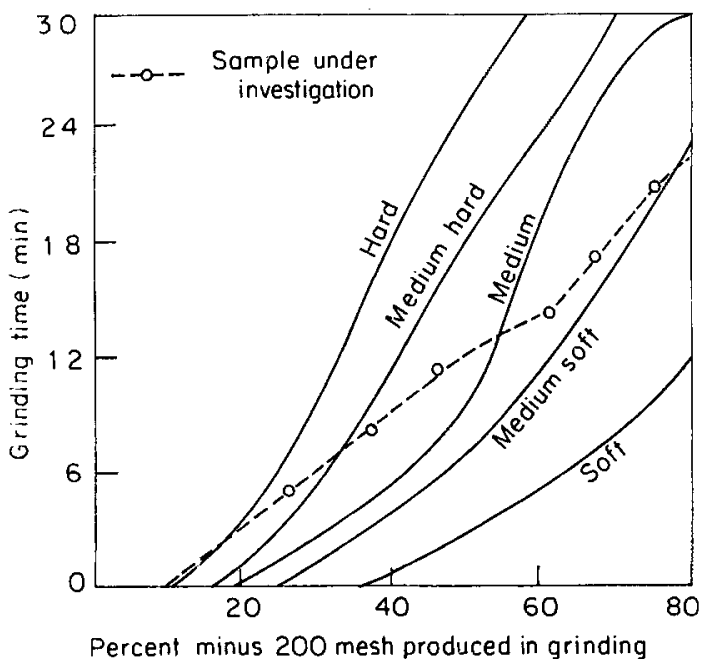

Figure 1. Grinding tests on run of mine ore. 
earlier. As illustrated in figures $2 \mathrm{a}$ and $2 \mathrm{~b}$, the optimum mesh of grind was $74 \cdot 6 \%$ minus 200 mesh.

\subsection{Conventional flotation versus reverse flotation}

A series of flotation tests, both conventional and reverse, were carried out on feed after magnetite removal by magnetic separation. In conventional flotation, apatite was floated employing fatty acids and its soaps while depressing silicate gangue minerals using sodium silicate.

In reverse flotation, attempts were made to float mica, ferromagnesian and other silicate minerals using cationic collectors (amines and its acetates), while depressing apatite by phosphoric acid.

The results of conventional flotation were encouraging and hence conventional flotation route was chosen.
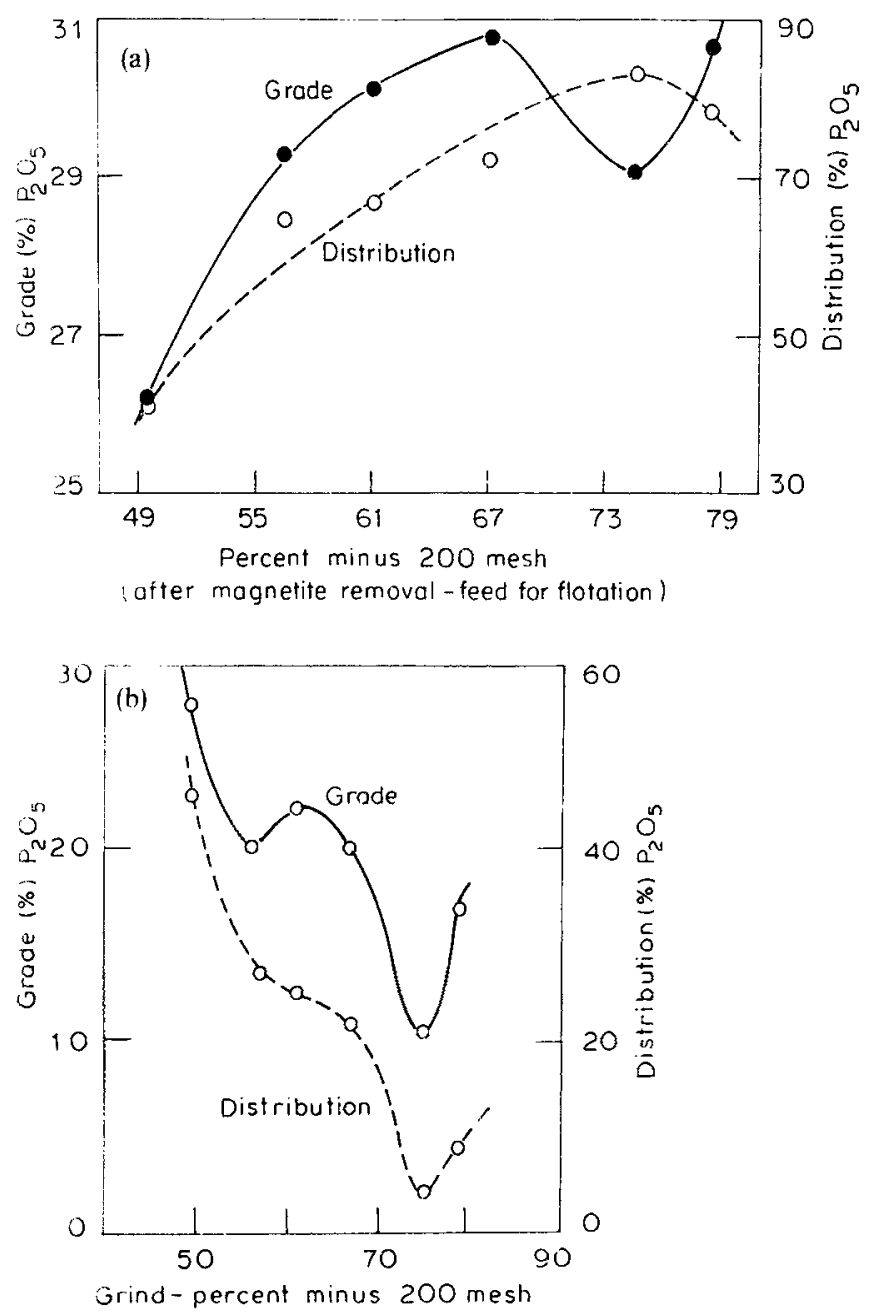

Figure 2. Mesh of grind optimization. a. Concentrate grade, distribution curves. b. Tailings grade, distribution curves. 


\section{3 pH optimization}

To determine the optimum $\mathrm{pH}$ during conventional flotation, three flotation tests were carried out on flotation feed (after magnetite removal), maintaining the $\mathrm{pH}$ of the flotation pulps as 6-6.5 (by $\left.\mathrm{H}_{2} \mathrm{SO}_{4}\right), 7-7.5$ (natural) and 9-9.5 (by $\mathrm{NaOH}$ ), at optimized grind ( $74.6 \%$ minus $200 \mathrm{mesh})$, using sodium oleate ( $2 \mathrm{~kg} /$ tonne) and pine oil $(0.056 \mathrm{~kg} /$ tonne). The quantity of sodium oleate was increased from 1.60 to $2.00 \mathrm{~kg} /$ tonne to ensure a cleaner rougher tailing. Accordingly the flotation time amounted to 10 minutes (instead of 8 minutes). As shown in figure 3 , the test results indicated the optimum $\mathrm{pH}$ of the pulp as $7-7 \cdot 5$ (natural).

\subsection{Depressant (sodium silicate) dosage}

To determine the optimum dosage of sodium silicate, three flotation tests were carried out employing $0.75,1.00$ and $1.25 \mathrm{~kg} /$ tonne sodium silicate at the optimized grind of $74.6 \%$ minus 200 mesh and at $\mathrm{pH} \mathrm{7-7.5}$. The results shown in figure 4 indicate the optimum dosage of $\mathrm{Na}$-silicate to be $1 \mathrm{~kg} /$ tonne.

\subsection{Collector-frother selection}

To ascertain the best collector-frother combination for apatite flotation, a number of conventional flotation tests were carried out using various reagent (collector-frother) combinations such as Turkey red oil plus pine oil (TRO), aeropromoter $(801+825)$

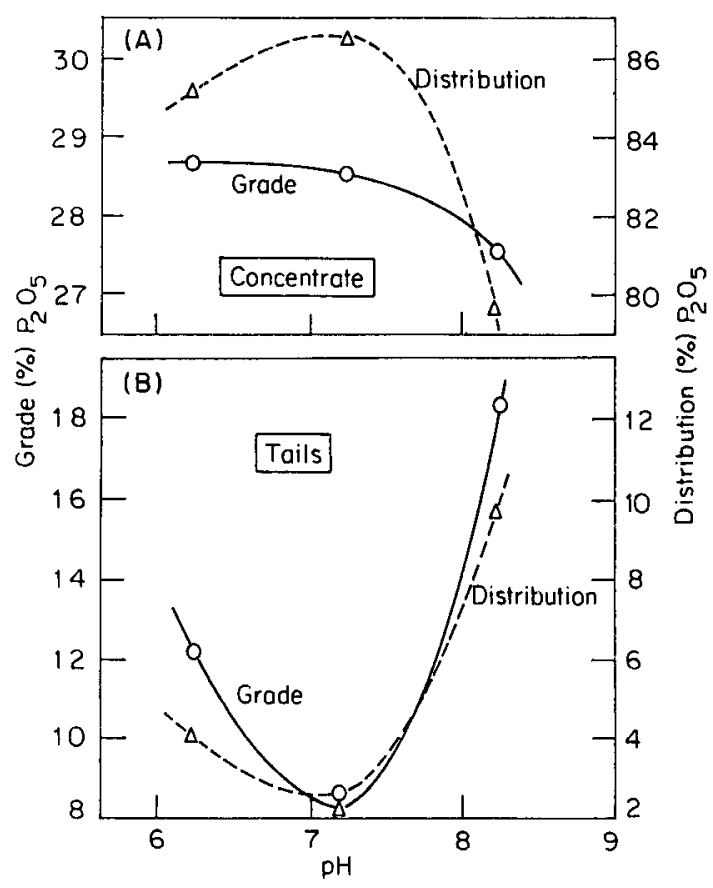

Figure 3. Effect of $\mathrm{pH}$ on apatite flotations. 


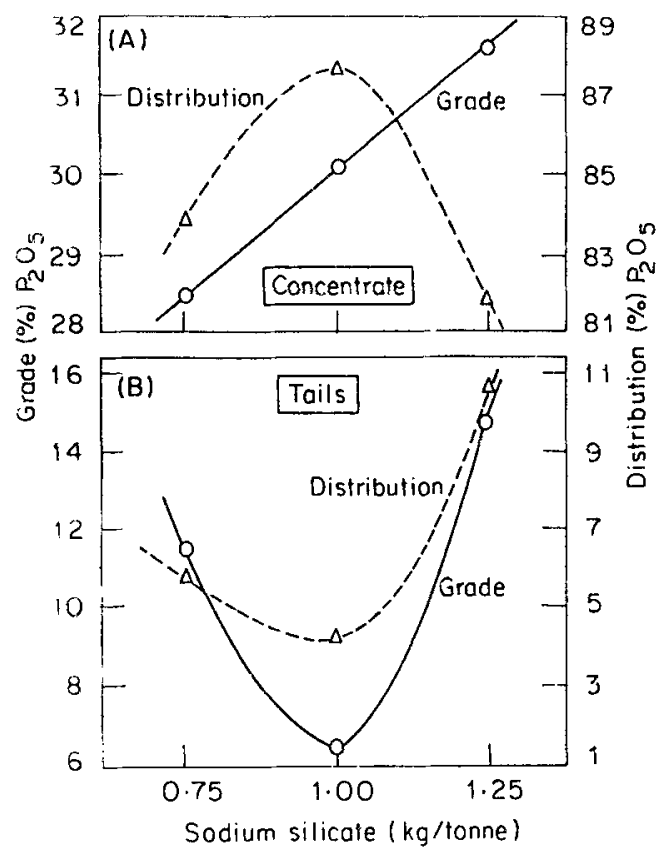

Figure 4. Effect of Na silicate dosage on apatite flotation.

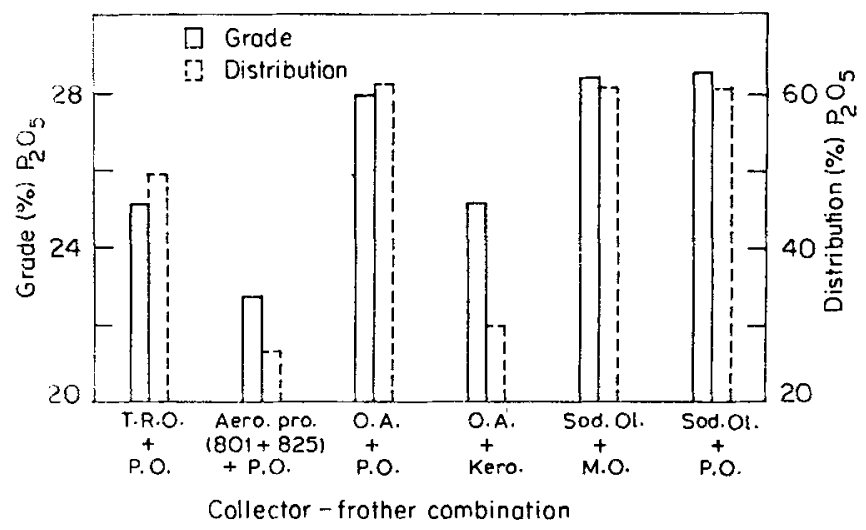

Figure 5. Effect of different collector-frother combinations on apatite flotation.

(American Cynamid Co.) plus pine oil, oleic acid plus pine oil (OA), oleic acid plus kerosene oil and sodium oleate plus pine oil, at an optimized grind of $74.6 \%$ minus 200 mesh at pH 7-7.5 with a sodium silicate dosage of $1.00 \mathrm{~kg} /$ tonne. The results are shown in figure 5 . The sodium oleate-pine oil combinate was found quite efficient for apatite flotation.

\subsection{Collector (sodium oleate) dosage}

To ascertain the optimum sodium oleate dosage, three flotation tests were carried out employing $1.50,2.00$ and $2.50 \mathrm{~kg}$ /tonne sodium oleate (stage addition) at an 
optimized grind of $74.6 \%$ minus 200 mesh, $\mathrm{pH}$ of $7-7.5$ and a sodium silicate dosage of $1.00 \mathrm{~kg}$ /tonne. As shown in figure 6 , a dosage of $2 \mathrm{~kg} /$ tonne is recommended for apatite flotation.

\subsection{Process flowsheet}

The rougher concentrate produced under the above mentioned flotation conditions and reagent dosage was further cleaned thrice in order to achieve the required grade. Sodium silicate additions at a dosage of $0.50,0.25$ and $0.25 \mathrm{~kg}$ /tonne and a flotation time of $3,2.5$ and 2.5 minutes during I, II and III cleaning stages respectively, was found adequate.

The test results summarized in table 1 indicate that by wet magnetic separation followed by flotation of the non-magnetics with three cleaning stages, a final apatite concentrate assaying $37 \cdot 18 \% \mathrm{P}_{2} \mathrm{O}_{5}$, could be obtained with about $80 \% \mathrm{P}_{2} \mathrm{O}_{5}$ recovery.

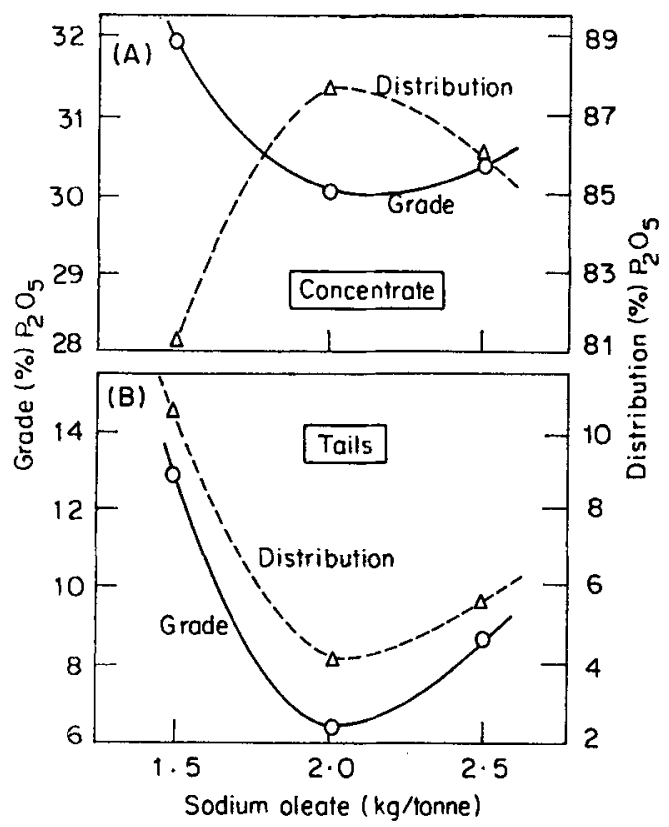

Figure 6. Effect of collector (Na-oleate) dosage on apatite flotations.

Table 1. Assay and distribution of various flotation products.

\begin{tabular}{lccc}
\hline Product & Wt \% & $\begin{array}{c}\text { Assay } \\
\left(\% \mathrm{P}_{2} \mathrm{O}_{5}\right)\end{array}$ & $\begin{array}{c}\text { Dist. } \\
\left(\% \mathrm{P}_{2} \mathrm{O}_{5}\right)\end{array}$ \\
\hline Non-magnetic fraction & & & \\
III Cleaner conc. & $20 \cdot 60$ & $37 \cdot 18$ & $79 \cdot 1$ \\
III Cleaner tails & $1 \cdot 50$ & $15 \cdot 0$ & $2 \cdot 3$ \\
II Cleaner tails & $2 \cdot 00$ & $11 \cdot 47$ & $2 \cdot 4$ \\
I Cleaner tails & $4 \cdot 12$ & $9 \cdot 18$ & 3.9 \\
$\quad$ Rougher tails & $6 \cdot 42$ & $6 \cdot 36$ & $4 \cdot 2$ \\
Magnetic fraction & 65.36 & $1 \cdot 2$ & $8 \cdot 1$ \\
\hline
\end{tabular}




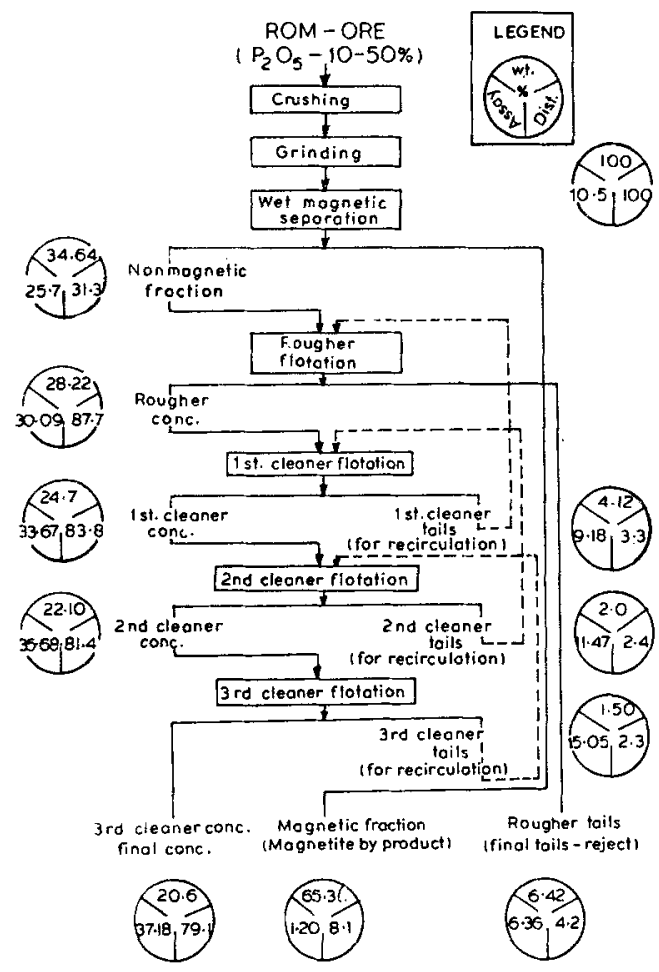

Figure 7. General process flowsheet recommended for beneficiation of magnetite-apatite ore from Sung Valley, Shillong (Meghalaya).

The product assayed $37 \cdot 18 \% \mathrm{P}_{2} \mathrm{O}_{5}, 2 \cdot 33 \% \mathrm{SiO}_{2}, 1 \cdot 20 \% \mathrm{Fe}_{2} \mathrm{O}_{3}, 2 \cdot 59 \% \mathrm{Al}_{2} \mathrm{O}_{3}$, $48.80 \% \mathrm{CaO}, 1.58 \% \mathrm{MgO}$ and $1.65 \%$ LOI. The product contained about $90-92 \%$ apatite, $1 \%$ mica, $1 \%$ quartz, $1 \%$ opaques and $5-7 \%$ other minerals. This concentrate meets the specifications of phosphatic fertilizer industry.

A complete flowsheet is given in figure 7 . The corresponding wt $\%$ recovery, percentage distribution and assay of $\mathrm{P}_{2} \mathrm{O}_{5}$ are also indicated at each stage of the process.

\section{Conclusion}

A low grade magnetite-apatite sample from Sung Valley, Shillong, Meghalaya State could be efficiently beneficiated by wet magnetic separation-cum-flotation technique to obtain an apatite concentrate assaying more than $37 \% \mathrm{P}_{2} \mathrm{O}_{5}$ from a feed assaying about $10 \% \mathrm{P}_{2} \mathrm{O}_{5}$. The concentrate could be used for the manufacture of phosphatic fertilizers. The magnetite obtained as a byproduct after wet magnetic separation of the ore, could be effectively used in the coal washing industry.

\section{Acknowledgements}

Sincere thanks are due to $\mathrm{Mr} \mathrm{D} \mathrm{N}$ Bhargava for his keen interest and valuable 
suggestions. The authors gratefully acknowledge the valuable suggestions from Shri K Satyanarayana and Mr G M Rao. Thanks are also due to Mr M G Raut and Mr J P Mishra, for their assistance.

\section{References}

Shivananda S R, Sankaran R N, Dwivedy K K and Jayaram K M V 1981 in Proc. Symposium on Advances in Science and Technology of Mineral Beneficiation in India, pp 496-502 